\title{
Urban Geography and the Production of Socio-Environmental Inequalities
}

\author{
Marc Parés \\ Geography Department, Universitat Autònoma de Barcelona, Cerdanyola del Vallès, Spain \\ Email: marc.pares@uab.cat
}

Received June 6, 2013; revised July 12, 2013; accepted August 5, 2013

Copyright (c) 2013 Marc Parés. This is an open access article distributed under the Creative Commons Attribution License, which permits unrestricted use, distribution, and reproduction in any medium, provided the original work is properly cited.

\begin{abstract}
In this article we use the Urban Political Ecology approach to show that by analysing governance networks we can better understand the production of certain socio-environmental transformations that negatively affect some social groups while benefiting others. Drawing upon two case studies in the UK, the article explores the dialectical relationships between different modes of urban governance on one hand and the socio-environmental transformations fulfilled in each case study on the other hand. The article concludes that although urban regeneration policies are always constrained by the neoliberal established framework of power relations, policy outputs and outcomes could be very different from one place to another, shaping uneven socio-environmental constructions. Finally, we make some recommendations in order to stimulate the production of more sustainable communities in the future.
\end{abstract}

Keywords: Urban Regeneration; Governance; Urban Political Ecology; Environmental Justice; Sustainable Communities

\section{Introduction}

Geography has largely tried to explain how cities have been produced along history and across space. In line with this goal David Harvey made an outstanding contribution in 1989 formulating a complete theory to interpret the urban process under capitalism. After that, and among other contributions, Harvey also evolved a socioenvironmental critical view undertaking a very important analysis of how geographical differences are produced in terms of social and environmental justice [1]. More recently, Urban Political Ecology (UPE) has emerged as a new geographical approach to environmental urban problems. UPE is concerned with analysing the relationships of social power behind the historical and geographical processes involved in the urbanization of nature [2].

Urban policies devised to improve, change or renew urban areas have been implemented in the UK since the 1950's. However, it is only from the 1990s that these policies have gone by the name of "urban regeneration", focusing policy emphasis on integrated treatments [3]. While other forms of urban policies have been basically focused on physical aspects, urban regeneration policies have promoted a more comprehensive approach, reintroducing a strategic perspective and achieving a greater balance between public and private funding. During the last decade, furthermore, the discourse on urban policies has emphasized the role of the community (with new forms of network governance) and has introduced the broader idea of environmental sustainability [4]. The New Deal for Communities programme and the Sustainable Communities Plan, launched by the New Labour government in 1998 and 2003 respectively, clearly exemplify this novel orientation of urban policies in the UK [5]. As well as using a comprehensive approach, current urban regeneration policies tend to be formulated through new forms of network governance and usually incorporate sustainability as one of their primary aims. In this vein, achieving more sustainable communities has become one of the main targets in western urban regeneration policies.

In the research presented here we analyse the relationship between these two salient features of urban policies: governance networks and urban sustainability. Several debates have emerged in recent years on these two dimensions of urban regeneration. On the one hand, a large number of contributions question the democratic quality of network governance arrangements (e.g. [6-8]) while, on the other hand, several authors mistrust the "goodness" of sustainable development applied in these policies (e.g. $[9,10])$. Probing these debates carefully, the 
article explores how new forms of neighbourhood governance are related to the contents of urban regeneration policies (policy outputs) and, consequently, to the socioenvironmental transformations of the city produced by these policies (policy outcomes). More specifically, our research aims to provide empirical evidence to test the hypothesis that comprehensive and more "sustainabilityoriented" policy outputs tend to be associated with more "democratic" modes of governance.

There is a large body of literature analysing the variability of urban governance and several models have been identified (e.g. [11-13]). The majority of these contributions have examined the causes that explain why a certain mode of urban governance is adopted in each case (e.g. [14-17]). Yet as far as we know, there has been very little research investigating the consequences of these modes of governance in terms of policy outputs and only a few of these contributions have observed a relationship between modes of governance and policy outputs in urban regeneration processes [18]. These last contributions have been focused on the role of citizen participation in governance networks and have analysed policy outputs in terms of comprehensiveness and social orientation. In a similar manner to these publications we also sustain that there is a dialectical relationship between the way urban policies are performed (its mode of governance) and their contents (in output terms). In addition, we provide new perspectives on three aspects: Firstly, rather than conceiving governance only as an umbrella for citizen participation we understand it in a broader way, taking into account all kinds of formal and informal relationships between the actors that constitute a network of governance. Secondly, our policy concern is not on the social contents of urban regeneration but on socio-environmental sustainability. And thirdly, our interest is not only in policy outputs but also in policy outcomes, namely how neighbourhoods are finally transformed.

Departing from UPE, we conceive the city as a socioecological process wherein environments are produced reflecting positions of social power [19]. From this conception two key assumptions arise, which are the basis of our analysis. First, we consider that cities are a result of a continuous metabolic process of transformation and production of urban environments; and throughout this metabolic process nature is mobilized, transformed and produced. Our research provides an exploratory analysis of how urban regeneration policies, determined by one or another model of governance, produce and transform the urban socio-environmental conditions of neighbourhoods and cities. Second, this endless production of urban environments reproduces the social inequalities of the system of production. Briefly, as Swyngedouw points out [20], the material conditions embedded in these urban environments are not independent from social, political and economic processes. These material conditions are controlled by certain elites and respond to their own interests, while in general negatively affecting other social groups.

Following this approach and through two case studies in the UK (Hulme and Salford) our empirical research shows that uneven policy outputs and outcomes are explained by a complex system of interdependent factors and power relations that, under institutional regimes of urban governance, are (re)producing new kinds of socioecological configurations. While both selected policies were designed during the beginning of the 1990s and, therefore, were not conceived in terms of what we call now "sustainable communities", in both cases different governance networks operated to transform the city through an area-based urban programme. Consequently, new socio-environmental constructions were produced. Beyond that, these cases are useful for our investigation because they have allowed us to carry out a policy outcome analysis.

\section{Methods}

To achieve our research purpose we worked with a comparative case study methodology [21], analysing two projects of area-based urban regeneration carried out at the end of the last century. The empirical investigation is focused on the UK urban policy, as it is in this country where network governance and sustainable community approaches have been largely performed. According to our goals we were interested in finding variability in the modes of governance, to see if this variability produced or not differences in the socio-environmental dimensions of urban policies. In order to reduce the variability of contextual variables we decided work with two cases of the same urban region: the Grater Manchester.

And last, but not least, as we were interested not only in policy outputs but also in policy outcomes, our case studies needed to have been completely implemented. Because we aimed to assess the real transformation of the city and its socio-environmental impacts, all the measures and actions of the regeneration programmes that we chose had to be completed some years ago. Obviously, in doing that we are analysing accomplished policies from the past through the lens and discourses of the present. The point, however, is that those policies analysed must have been organized through a governance network and must have produced socio-environmental transformations in their neighbourhoods. Notwithstanding other advantages, this methodological approach has been of primary importance in reaching significant conclusions about how uneven socio-environments are produced, which will be very useful for future urban policies that pursue a generation of more sustainable communities.

Hulme and Salford were chosen as two case studies 
that, having some historical and geographical similarities, also had differences in the mode of governance performed and the outcomes of the regeneration process. In both cases there was a wish to environmentally improve an urban area and that was very important for our research. Salford Quays is a significant case because the project aimed to create a pleasant built environment with clean water and green areas in order to ameliorate the quality of life. In Hulme "sustainability" was the central concept of the guide that should orientate the regeneration process. In both cases a structure of governance (with several stakeholders) was performed to carry out the process. However, while Hulme is a significant case because citizens were very active and they were engaged in the network of governance, in Salford there was almost no-one living there when the regeneration occurred and the network of governance was performed without involving the rest of the citizens of Salford. As we will see, the socio-environment produced in each case was clearly very different.

In each case study institutional regimes, policy networks, policy outputs and policy outcomes were analysed. A thorough analysis of policy documents, media and other sources of information was done and several in-depth interviews to relevant actors (policy-makers, representative of citizen groups and professionals) were performed in both cases (6 in Hulme and 4 in Salford).

\section{The Hulme City Challenge}

The first case study analysed in our research is that of Hulme, where urban regeneration was carried out through the City Challenge Programme implemented from 1992 to 1997. This neighbourhood of Manchester, very close to the city centre and next to the university, was developed as a residential zone for factory workers early in the nineteenth century. In 1930 Hulme had 130,000 dwellers and often is remembered as the worst slum of England. In this moment, a slum clearance programme begun and some council houses were built. That started a process of population decline which continued till 1990s. In 1940s and 1950s the clearence programme was accelerated and a number of traditional brick-built flats were erected. By the end of 1950s the first multy-storey block had been built in Hulme, and ten more followed in the next years. By the mid 1960s the council, already facing massive demand for housing from a rapidly-expanding local population, decided to plan over 5000 units of industrialised deck access housing. By 1971 the area was endowed with a mixture of new concrete tower blocks and deck-access dwellings for a total of about 10,000 people. Pedestrian segregation was also introduced but few community or commercial facilities were provided to the neighbourhood. The buildings soon developed technical faults and due to the little maintenance and the lack of management to deal with these problems Hulme rapidly became "hard to let". Most of the problems were concentrated in the Crescents, an area with four blocks of five floors, each of which had a length of a quarter mile and 944 flats. The four blocks were flattened through the regeneration programme and this was the main area for rebuilt.

To sum up, before the regeneration process launched in Hulme with the City Challenge programme this Manchester neighbourhood was one of the most deprived areas of England, with high rates of poverty and crime, enormous deficits of housing, a sub-standard in commercial and education facilities, a bad environmental quality, a high unemployment rate and a big concentration of specific social groups. Practically no families with children inhabited the neighbourhood and most of the dwellings were young and old people. Furthermore, there also was a high rate of vacant homes and the neighbourhood was losing population because nobody wanted to go there to live [22].

Despite developing a great number of studies about Hulme's needs during the 1980s, it was not until 1991 that the conservative Government of John Major promoted the City Challenge programme in order to regenerate this and other deprived areas in the UK. Previously, in 1988, the central government had already decided to invest a large amount of money in Hulme with a pilot programme called HAT. However, tenants were mobilized against this initiative arguing that the programme was absolutely not responding to the wishes of the local community and was only a physical intervention that didn't resolve the social and economic problems of the neighbourhood.

\subsection{The Governance}

Before applying for funding the City Council promoted a really participatory diagnosis of Hulme that was the basis for the Action Plan. Nevertheless, after that, the governance system set out in Hulme was based on a clearly restricted partnership, with a cross-departmental management, a multilevel institutional representation and an important role being given to private developers and housing associations. As a consequence both of them had a high influence on final policy outputs. At the same time, however, open acts of consultation during the implementation of the programme were also important and tenants played an active role through a specific participatory project. Furthermore, important community initiatives were launched in the neighbourhood and most of them are still functioning. That is the case, for instance, of the "Hulme Community Garden" or the housing cooperative "Homes for Change". 


\subsection{The Outputs and the Outcomes}

One of the main outputs of the process, which was not exactly converted into an outcome, was the production of the "Hulme Design Guide". The guide was the result of a participatory process initiated by the partnership organization as a consequence of a demand made by tenants associations and some important architects of the area. The guide was made to be used in the evaluation of all applications for planning permission in the new Hulme, and consists of a framework of 53 written and drawn recommendations grouped, as: streets, integration, density, permeability, routes and transport, landmarks, vistas and focal points, definition of space, identity and sustainability. The guide included a methodology for evaluating the sustainability of urban design elements (mostly housing) in the context of a design guide for inner city area reconstruction. The production of this guide shows the emphasis of the Hulme regeneration process to generate a community-based approach aiming to develop a new urban neighbourhood and contextualising the concept of sustainability by putting various detailed evaluation techniques in a framework which cross-refers to other aspects of urban design.

Considering the regeneration outcomes there is evidence that, after the urban regeneration process, environmental and social conditions of the neighbourhood have radically changed. The investment in housing has produced a real shift on the area and Hulme has now a more liveable urban environment, with more open spaces and better transport. Tenant diversification has been achieved, drastically reducing the number of public houses and increasing the private sector, but with a clear predominance of housing association homes. However, although Hulme is now more socially diverse, it is not a balanced community and the number of families with children living there is still low. As far as the economic dimension is concerned, the main achievement has been the location of a big supermarket in the area, importing flows of capital to the neighbourhood but failing to promote retail and create employment, which was one of the primary targets of the programme.

Finally, it is important to highlight that after the regeneration process Hulme still had affordable homes and, therefore, gentrification trends were absolutely avoided. Moreover, most of the people that lived in Hulme were generally kept in the neighbourhood after the City Challenge implementation. Undoubtedly, these two things (affordable homes and the right to come back to the neighbourhood) were achieved by tenant's pressure. Precisely these two elements are crucial to explain why, lastly, in the Hulme case most of the regeneration programme benefits were benefits for local people.

\section{Salford Quay's Regeneration Programmes}

Salford, located $4 \mathrm{~km}$ to the west of Manchester, has a long history of 25 years transforming the built environment through several programmes of urban regeneration, struggling with deprivation. Salford City Council has also a long record of community involvement in its regeneration programmes but in Salford Quays there was not a local community to engage and the governance structure performed did not assign a relevant role to Salford citizens.

The regeneration process begun with the transformation of Salford Docks into Salford Quays. Queen Victoria originally opened the docks in 1894, linking Manchester to the see through the Manchester Ship Canal and becoming the Britain's third largest port. Almost one century later, in the 1970s, the docks rapidly declined, over 3000 people lost their job and the area became derelict.

With all the docks closed and with rising levels of unemployment affecting surrounding areas, in 1984 the Salford City Council purchased the docks and took the lead in driving forward several regeneration programmes, both to secure the re-use of derelict land and to tackle inner city social and economic deprivation. After a first agreement with Urban Waterside Ltd. to transfer dock 6 on condition that further private investment, the City Council recognised the need for a development plan to provide confidence to both public and private sector long-term investors. A Salford Quays Development Plan was published in 1985 and the government agreed in principle to the City Council leading the dock's regeneration, providing a unique rolling programme of derelict land and urban programme funding.

Nevertheless, rather than land-use pressure remaining constant over time, the pace of development in Salford Quays has occurred in waves shaped by market forces, government investment, transport infrastructure improvements, and key property developments, including early catalysts which helped to install greater confidence in the site [23]. In 1988 the City Council reviewed the original development plan highlighting potential leisure, cultural and tourism opportunities of the area. The Salford Centre for the Performing Arts (revised as The Lowry) became the icon of this new regeneration stage that, with a new masterplan, was developed between 1996 and 2005.

Finally, in 2006 a new stage was opened in the regeneration process aiming to turn Salford Quays into a Media City, fostering an environment that allowed and encouraged the expansion of digitally-driven industries. The MediaCityUK became a project of national and international importance, rivalling other media cities emerging around the world. The move of BBC five departments from London to Salford Quays confirmed in 2007 became the key factor to guarantee the success of the project. 


\subsection{The Governance}

Urban politics in Salford Quays have been based on a very good interaction between local and central government, both acting in a very pragmatic way. That is an important difference between Salford and Manchester, where tensions between central and local governments determined the governance system established in Hulme. In Salford, however, community was less involved and the governance system was based in a hierarchical model involving private sector and local and central government.

The role of private sector is especially relevant in this case study. During the first stage of the regeneration process (1985-1996) the private sector invested approximately $300 \mathrm{M} £$, while the public sector only invested 40 $\mathrm{M} £$. The public sector investment rose up in the second stage (1996-2005) until $105 \mathrm{M} £$, but the private sector investment was still greater, $345 \mathrm{M} £$. Nevertheless, the biggest gap between both sectors has been predicted in the current stage (2005-2020), with only $40 \mathrm{M} £$ of public investment against $760 \mathrm{M} £$ of private investment.

The main company investing funds in the regeneration process has been Peel Holdings (currently The Peel Group), the parent company of the Manchester Ship Canal Company. The Peel Group is a diversified real estate, transport and infrastructure investment company and is the largest property investment company in the UK. They are the owners of major landmark developments within the region, including The Trafford Centre, which is one of Europe's most stunning shopping centres. Moreover, the Peel Group portfolio also contains infrastructures like the Manchester City Airport, the Liverpool Airport or, more recently, the Scout Moor Wind Farm and the Ocean Gateway. Peel Holding had, and continues to play, a significant role in the regeneration of Salford Quays. Among others, this company developed a 21,000 $\mathrm{m}^{2}$ office building, known as Quay West; The Victoria, a luxury office development of approximately $35,000 \mathrm{~m}^{2}$, and made substantial contributions to the funding of The Lowry and The Imperial War Museum.

\subsection{The Outputs and the Outcomes}

The regeneration programme carried out in Salford Quays was clearly successful as a new urban environment was created, a new commercial area was generated and new yuppie style inner-city apartments were developed. The regeneration process has been internationally recognized and the City Council has labelled it as an "award-winning" project, even though the BBC MediaCity complex awarded "Carbuncle Cup" for ugliest new building in Britain in 2011.

The plan aimed to place emphasis to work, leisure and residential uses, providing infrastructures to change the accessibility and the social and economic dynamics of the area. All these targets were absolutely achieved and, effectively, the regeneration process was based on commercial stagnation, creating an attractive waterfront with economic and cultural activities. However, some of the first purposes of the Development Plan were changed with the Reviewed Strategy and, finally, a shopping mall and several large-scale speculative offices not only were allowed but also were promoted by the City Council.

In environmental terms, improvements in water quality have been one of the main outcomes, together with ecological corridors, pedestrian areas, cicleways and public transport expansion. In economic terms, the case study is a clear example of urban entrepreneurialism. Certainly, in 1987 the area only had 255 jobs and in 2006 the number of jobs increased till 13,000. Local residents, though, did not occupy most of these jobs. Salford Quays, with over 150 businesses, 2000 new dwellings and 18,500 $\mathrm{m}^{2}$ of office space, has become now an enclave of wealthy professionals. This new jobs, therefore, were not addressed to Salford's unqualified residents, moreover, any strategy was carried out in order to improve the employability of these people.

A similar thing occurred with new housing supply of the area. After the first stage of the regeneration process housing prices of the area extremely increased, producing an extreme form of gentrification. The development of the Lowry centre, among others, provided Salford Quays with an internationally renowned building and arts venue, and prompted further waves of residential development activity. However, these new residential development were not affordable for local people of the surroundings. In fact, more affluent people moved into an area that had already been upgraded for them, excluding the pre-existing poorer dwellers from the ability to buy property in their own neighbourhood.

\section{Discussion}

The first point that should be highlighted from the case studies is that regeneration programmes in the UK have been and are still delivered in a very top-down manner. As the framework is already given, there is little space for a political debate in terms of what Kooiman [24] calls the meta-governance dimension of policies. Moreover, we have also seen that public-private partnerships, used in both cases as the main mechanism of urban governance, tend to be restricted spaces of deliberation where some stakeholders are present while others not. In both neighbourhood governance networks some social groups have been excluded from the partnerships and, consequently, some geometries of power have been reproduced. Furthermore, as each actor uses its own (and asymmetrical) resources to have a certain amount of influence over the policy orientation, the network of gov- 
ernance becomes unequal too, unless some specific mechanisms had been planned to change this situation. Such reality is also in line with the literature that understands governance as a managerial approach in which geometries of power tend to be maintained [25,26]. Globally, thus, both urban policies analysed show that their networks of governance have significant democratic deficits concerning: the political debate, who participates in the network and what are the power relations inside these networks.

Despite these similarities, large differences have been also observed between governance networks shaped in Hulme and Salford. Undoubtedly, the findings of this study illustrate that uneven and shifting modes of governance can be identified, not only concerning how governance networks are performed but also as regards their democratic quality. While some modes of governance like the Hulme tenants participatory project try to involve the community in the urban regeneration process, others are primarily market-oriented and basically involve private agents. A case in point is the Salford Quays' regeneration programme. In fact we have seen that the democratic quality of a governance network can vary with time and inside the network. In Hulme, the partnership was extremely restricted and participation inside the partnership was carried out in very asymmetrical way, with considerable inequalities between actors. At the same time, however, some participatory initiatives were opened to all the community and they worked in a more democratic way, as the main critical social voices also recognized. In Salford, by contrast, the change has taken place across time. After a long first stage of non-participatory and market-oriented regeneration, now the City Council is trying to involve the community in its new urban policies. Therefore, our data strengthen the argument sustaining that governance could not be conceived as democratically good or bad by nature and, consequently, each governance network must be evaluated according to certain patterns of democratic quality.

As some authors have noted [27] these variegated forms of governance and these patterns of change must be understood in coexistence with and as a consequence of dependence on certain social, political and economic path dependencies. In the following sections we will see that many factors could explain this variety. From our point of view, though, the main point that should be stressed from our findings is that, even in a context where urban policies are delivered in a very centralised and top-down way; places, communities, local governments and neighbourhoods have their own agency to shape different modes of network governance with different degrees of democratic quality. Historical and geographical power relations, then, are crucial to understanding how different modes of governance networks are produced. In each place, therefore, a concrete network of governance will be continuously and dialectically shaped as a result of the specific historical and geographical power relationships that operate inside each neighbourhood and on different scales.

Although in both case studies we have seen that there is no space for a meta-governance political debate and that urban regeneration policies are always constrained by the neoliberal established framework of power relations, we have also found that urban governance approaches enable policy variation. What is more, this policy variation usually comes from the debate (more or less democratic) between different policy choices. In particular the urban policies implemented in Hulme, which are more community-oriented and based on affordable housing and environmental quality; are very different from those policies promoted in Salford which are clearly market-oriented and based on commercial stagnation.

A comparative analysis of both case studies shows that more comprehensive policy outputs tend to be related to more democratic modes of governance. In Hulme established a more democratic mode of governance was established than in Salford and its policy outputs reflected a wider integration of social, environmental and economic targets than those in Salford. While in Hulme a more active mobilization of tenants forced a higher social orientation of the Action Plan, in Salford citizens were only marginally involved and policy outputs omitted the social and the environmental dimension of the regeneration programme. Focusing our attention on environmental issues we can observe how in Hulme citizen's involvement prompted the introduction of environmental targets, not only in the Hulme Development Guide but also in some of the projects of the Action Plan. These environmental targets, moreover, were also conceived in terms of social justice. In Salford, by contrast, environmental goals were thought in terms of marketing environmentalism and urban entrepreneurialism.

As previous researchers have reported [18], the effect that democratic governance has on the comprehensiveness of policy outputs is not unidirectional at all but is dialectical and interactive. Performing a more democratic governance network contributes to the comprehensiveness of the regeneration policy and, at the same time, conceiving urban regeneration policies in a more comprehensive way implies that citizens must be taken into account. Although in the Hulme case study environmental targets were directly related to citizen's participation, some caution should be exercised concerning as to what extent these results can be generalized, since sustainability has become a depoliticised concept that could be introduced in many policy choices [28]. Probably, uneven environmental outputs could not only be explained by the democratic quality of governance net- 
works but should be explained by a complex system of interdependent factors.

Beyond policy output analysis, the primary goal of our research was to investigate how cities are produced and transformed (policy outcomes) through different modes of governance. Based on our case studies we can state that not only policy outputs but also socio-environmental constructions produced through urban regeneration policies are uneven. We observe that environments constructed with urban policies and also the social and economic conditions generated in each neighbourhood as a consequence of these policies are very diverse. Both, Hulme and Salford, have radically changed after the regeneration process, but they have changed in very different directions. Nowadays Hulme keeps part of its prior history. There is still a sense of community and there is evidence that the new neighbourhood was planned with some principles of social and environmental justice. On the contrary in Salford, the new neighbourhood of Salford Quays is an enclave of wealthy professionals lying close to areas of relative deprivation, raising questions about its social sustainability. This unevenness between both neighbourhoods is especially relevant when considering the benefits that urban regeneration had (or didn't have) for local communities. By and large, while Hulme's local residents have benefited from the regeneration process, in Salford urban regeneration led to gentrification and local residents were disadvantaged.

Social relations and inequalities inside the network of governance operate in the production of these new socioenvironmental constructions, even in Hulme, where the governance network was more democratic. The comparative analysis of our case studies suggests that the more unequal and hierarchical are the forms of governance, the more new socio-environmental constructions of the city respond to the interests of economic elites, forgetting the poorer social groups of local communities affected by urban policies. This is what occurred in Salford. At the same time, however, we can also state from our case studies that the more market-oriented and notcommunity-led are the urban regeneration policies, the more unequal and hierarchical tend to be the forms of governance. Thus again, the relationship between democratic governance and socio-environmental policy outcomes appears to be dialectical and interactive.

Although we cannot generalize the hypothesis that a more democratic governance network directly produces a more "sustainable" community, both our case studies definitively show that unequal (non-democratic) governance networks tend to produce socio-environmental injustice. As Raco noted [29], the problem appears when some institutions describe their unfair urban policies (involved in a rolled-out neoliberalism approach) as forms of sustainable communities, just because they are carry- ing out certain processes of consultation and are introducing environmental targets. In this context we sustain that rather than promote sustainable communities and in order to achieve socio-environmental justice, urban regeneration policies should further real democratic modes of neighbourhood governance.

Forces constraining democratic governance and socioenvironmental justice tend to be structural determinants that characterize the political and economic system. These systemic determinants perform the framework in which policies are delivered. For the last 30 years Neoliberalism has swept across the world shaping institutional frameworks and social relations. Its market forces and its structural power relationships have constrained not only the way in which urban policies have been made but also their outputs and outcomes. During this period all urban policies in the UK have been shaped inside the framework of the neoliberal political and economic system and, even in those cases where governance networks have been designed in a more democratic way; there has been no space for a real political debate questioning this framework. As a consequence, and coming back to our case studies, we can observe how both cases show that even though the urban policies developed were very different, they were both constrained by market forces. In Hulme, enhancing the market over the public sector, housing renewal was based on a reduction of public housing and an increase of private supply. Moreover, Hulme's failed economic strategy basically aimed to attract capital investment, which is a typical neoliberal urban strategy. In the end, little retail was developed in the neighbourhood and a big supermarket (a multinational company) was the main achievement of the regeneration programme in economic terms. In Salford, as we have seen, there is no doubt that the regeneration programme was absolutely market-oriented, not only in its conception but also in its policy practices and its results.

Nevertheless, analysing our case studies we have also observed that there are some opportunities to shape different modes of governance and to steer outcomes with policy variation. But, under what circumstances are the governance networks more democratic and the policies delivered more integrated, thus promoting socio-environmental justice? Drawing upon the Hulme and Salford case studies we can identify three main factors that enable integrated and democratic urban regeneration.

First, the Hulme case shows us how a previous social conflict and a high social activism forced the state to involve the community in the regeneration process. Participation in this kind of situations tends to be launched to avoid or to manage contestation. The existence of alternative political spaces, thus, may promote wider political debates and may lead the state to take into account the demands of civil society. That is what happened in 
Hulme, where a high social mobilization (especially headed by tenants associations), alternative spaces of thought and debate (for instance those promoting the Hulme Design Guide) and communitarian experiences (like Homes for Change or the Community Garden) generated a more participatory system of governance.

Second, as other authors have established previously [30], we can also conclude that path dependency is always important in enabling integrated and democratic urban policies. As we have already said, in Hulme a higher degree of protests and contestation preceded a more participatory system of governance. In Salford, by contrast, after 20 years of a very top-down and marketoriented urban development, nowadays the local government is having considerable difficulties trying to engage citizens in current urban policies.

Third, in those cases where the urban regeneration policy responds to a more communitarian system of values, norms and beliefs; and that is basically when these values, norms and beliefs are assumed by the City Council; then the model of governance tends to be more democratic. In Salford there was not a democratic model of network governance basically because the City Council and the conservative central government did not believe in community participation. However, more recently, with a labour central government the City Council adopted a more communitarian system of values, norms and beliefs and launched a broad based consultation process. It should be highlighted that in Hulme, by contrast, some key stakeholders actively defended the involvement of citizens in urban policies and that is one of the primary reasons to explain the higher degree of participation achieved in Hulme's regeneration process.

\section{Conclusion}

Without underestimate the systemic neoliberal determinants that perform the framework in which urban policies are delivered, we conclude that local agency could be triggered in order to stimulate the production of more sustainable communities in terms of socio-environmental justice. To achieve this target in future urban policies we suggest that at least three more elements should be taken into account. First, civil society must be active, forcing the state to involve the community in the regeneration process. Second, policy-making processes of the present will determine future urban policies. Therefore, the production of democratic and sustainable policies today will contribute to the production of sustainable communities tomorrow. And last, but not least, performing governance networks in a more democratic way will facilitate that urban policies respond a more communitarian system of values, norms and beliefs. In other words, the production of more sustainable communities in terms of socio-environmental justice implies to decide democratically (collectively and confronting discordant positions in terms of equality), which kind of environment we want to produce and how we want to transform (not to sustain) our unequal neighbourhoods.

\section{REFERENCES}

[1] D. Harvey, "Justice, Nature and the Geography of Difference,” Blackwell, Oxford, 1996.

[2] R. Keil, “Urban Political Ecology,” Urban Geography, Vol. 26, No. 7, 2006, pp. 640-651. doi:10.2747/0272-3638.26.7.640

[3] P. Roberts and H. Sykes, "Urban Regeneration,” Sage, London, 2006.

[4] P. Jones and J. Evans, "Urban Regeneration in the UK," Sage, London, 2008.

[5] R. Imrie and M. Raco, "Urban Renaissance? New Labour, Community and Urban Policy,” The Policy Press, Bristol, 2003. doi:10.1332/policypress/9781861343802.001.0001

[6] V. Guarneros-Meza and M. Geddes, "Local Governance and Participation under Neoliberalism: Comparative Perspectives," International Journal of Urban and Regional Research, Vol. 34, No. 1, 2010, pp. 115-129. doi:10.1111/j.1468-2427.2010.00952.x

[7] E. Sorensen and J. Torfing, "The Democratic Anchorage of Governance Networks,” Scandinavian Political Studies, Vol. 28, No. 3, 2005, pp. 195-218. doi:10.1111/j.1467-9477.2005.00129.x

[8] E. Swyngedouw, "Civil Society, Governmentaly and the Contradictions of Governance-beyond-the-State: The JanusFace of Social Innovation,” In: J. Hillier, F. Moulaert and S. Vicari, Eds., Social Innovation and Territorial Development, Ashgate, London, 2009, pp. 63-80.

[9] J. Agyeman, R. Bullard and B. Evans, "Exploring the Nexus: Bringing Together Sustainability, Environmental Justice and Equity,” Space and Polity, Vol. 6, No. 1, 2002, pp. 77-90. doi:10.1080/13562570220137907

[10] R. Krueger and D. Gibbs, “The Sustainable Development Paradox: Urban Political Economy in the United States and Europe,” The Guilford Press, New York, 2007.

[11] A. Di Gaetano and E. Strom, "Comparative Urban Governance. An Integrated Approach,” Urban Affairs Review, Vol. 38, No. 3, 2003, pp. 356-395. doi: $10.1177 / 1078087402238806$

[12] J. Pierre, "Models of Urban Governance. The Institutional Dimension of Urban Politics," Urban Affairs Review, Vol. 34, No. 3, 1999, pp. 372-396. doi:10.1177/10780879922183988

[13] K. Provan and P. Kenis, "Modes of Network Governance: Structure, Management, and Effectiveness," Journal of Public Administration Research and Theory, Vol. 18, No. 2, 2007, pp. 229-252. doi:10.1093/jopart/mum015

[14] G. Blakeley, "Governing Ourselves: Citizen Participation and Governance in Barcelona and Manchester," International Journal of Urban and Regional Research, Vol. 34 , No. 1, 2010, pp. 130-145. doi:10.1111/j.1468-2427.2010.00953.x 
[15] A. Cento and B. Jones, "Governance and Social Capital in Urban Regeneration: A Comparison between Bristol and Naples,” Urban Studies, Vol. 43, No. 4, 2006, pp. 767786. doi:10.1080/00420980600597558

[16] J. Pierre, "Comparative Urban Governance. Uncovering Complex Causalities,” Urban Affairs Review, Vol. 40, No. 4, 2005, pp. 446-462. doi:10.1177/1078087404273442

[17] C. Poppelaars, "Resource Exchange in Urban Governance. On the Means That Matter," Urban Affairs Review, Vol. 43, No. 1, 2007, pp. 3-27. doi:10.1177/1078087407302766

[18] M. Parés, J. Bonet and M. Martí, "Does Participation Really Matter in Urban Regeneration Policies? Exploring Governance Networks in Catalonia (Spain)," Urban Affairs Review, Vol. 42, No. 2, 2012, pp. 238-271. doi:10.1177/1078087411423352

[19] N. Heynen, M. Kaika and E. Swyngedouw, "In the Nature of Cities. Urban Political Ecology and the Politics of Urban Metabolism,” Routledge, New York, 2006.

[20] E. Swyngedouw, "Social Power and the Urbanization of Water: Flows of Power," Oxford University Press, Oxford, 2004.

[21] R. K. Yin, "Case Study Research. Design and Methods," Sage, London, 2003.

[22] European Institute for Urban Affairs, "Hulme City Challenge. Did It Work?” Manchester City Council, Manchester, 1998.

[23] S. Henderson, S. Bowlby and M. Raco, "Refashioning Local Government and Inner-City Regeneration: The Sal- ford Experience,” Urban Studies, Vol. 44, No. 8, 2007, pp. 1441-1463. doi:10.1080/00420980701373495

[24] J. Kooiman, "Modern Governance: New Government-Society Interactions,” Sage, London, 1993.

[25] B. Jessop, "Liberalism, Neoliberalism and Urban Governance: A State-Theoretical Perspective," Antipode, Vol. 34, No. 2, 2002, pp. 452-472. doi:10.1111/1467-8330.00250

[26] E. Swyngedouw, "Governance Innovation and the Citizen: The Janus Face of Governance-beyond-the-State," Urban Studies, Vol. 42, No. 11, 2005, pp. 1992-2006. doi:10.1080/00420980500279869

[27] N. Brenner, J. Peck and N. Theodore, "Variegated Neoliberalization: Geographies, Modalities, Pathways,” Global Networks, Vol. 10, No. 2, 2010, pp. 182-222. doi:10.1111/j.1471-0374.2009.00277.x

[28] E. Swyngedouw, "The Post-Political City,” In Bavo, Eds., Urban Politics Now. Re-Imaging Democracy in the Neoliberal City, NAI Publishers, Rotterdam, 2007, pp. 58-77.

[29] M. Raco, "Sustainable Development, Rolled-Out NeoLiberalism and Sustainable Communities," Antipode, Vol. 37, No. 2, 2005, pp. 324-346. doi:10.1111/j.0066-4812.2005.00495.x

[30] F. Moualert, F. Martinelli, S. González and E. Swyngedouw, "Social Innovation and Governance in European Cities: Urban Development between Path Dependency and Radical Innovation," European Urban and Regional Studies, Vol. 14, No. 3, 2007, pp. 195-209. doi:10.1177/0969776407077737 